\title{
ON THE BIRDS OF THE DISTRICT OF TALASEA IN NEW BRITAIN.
}

\section{BY ERNST HARTERT.}

THE large island of New Britain (Neu Pommern), the largest of the

Bismarck Archipelago, east of New Guinea, is, zoologically, the best-known island of the group; quite a number of good collectors and ornithologists have been there, and yet it remained almost unknown with the exception of the northernmost peninsula, called Gazelle Halbinsel. It was therefore that Lord Rothschild induced Mr. Albert F. Eichhorn to go to the western parts to collect. As he had no vessel of his own, he was obliged to go where ships could take him, and decided to go to Talasea. Of this district he writes as follows: "Our camp was pitched at 1,200 feet, the place being chosen for the water found there. The mountains above reach an elevation of 3,400 feet, and up to that altitude my men and myself have collected. The surrounding country is dotted with geysers and hot mud springs, and sometimes their sickening sulphur fumes drifted up to and across the camp. The scrub is virgin, huge ficus trees towering above the others. The soil is very loose volcanic young formation. No natural grass patches are within sight, except a little one made around the Government station, hence the absence of birds inhabiting grass-land. The native population inland is very sparse, so it is mostly impossible to get carriers and food."

The collection made by Mr. Eichhorn is a very interesting one. It contains specimens of the very interesting and (in collections) rare Henicophaps foersteri (only known since 20 years), the rare Henicopernis longicauda infuscatus, Halcyon albonotata!, Monarcha hebetior !, Rhipidura dahli dahli!, and many other fine New Britain birds in beautiful series, as well as two unexpected novelties: Accipiter luteoschistaceus and Turdus talasea. The absence of the much desired Tyto aurantia (Salvad.), Excalfactoria lepida, Rallidae, Merops salvadorii, and of Munia is regrettable, but these forms, or at least some of them, do not seem to exist where Eichhorn collected, or may be are extremely rare there.

With the help of Reichenow's "Vögel der Bismarckinseln" in Mitt. Zool. Samml. Berlin, i. 3 (1899) it is now comparatively easy to work out a collection from New Britain. Since then, however, several articles on the birds of that island have appeared :

Hernroth, Ornithologische Ergebnisse der "I. Deutschen Südsee Expedition von Br. Mencke " in Journ.f. Orn., 1902 and 1903.

Отto Meyer, "Die Vögel der Insel Vuatom," in Natur und Offenbarung, vol. $52,1906$.

Vuatom, Watom, or Uatom is a small island just north of the Gazelle Peninsula. Meyer observed there not less than 87 different species, which is a considerable number for such a small island. His article contains many valuable biological notes. Most of the specimens which he collected are preserved (mounted) in the convent of the fathers of the Heart of Jesus in,Hiltrup near Münster i. Westf., where I had the pleasure, together with Professor Reichling, to look over the collection. 
W. Meyer, “Zur Vogelfauna des Bismarck-Archipels," in Ornith. Monatsber. 1909, pp. 33-38.

This article contains interesting notes on birds from New Britain, among others the description of plumage, nest, and eggs of an apparently undescribed Reed-Warbler. It contains further the description of two supposed new birds :

Halcyon toriu, a Kingfisher hitherto unknown to oceur in New Britain or anywhere else in the Bismarck Archipelago. The description, however, agrees in every way with that of the male of Halcyon macleayi, under which name Father Meyer has sent specimens to Berlin and Hiltrup ; the latter has been sent to Rome, and already O. Meyer knew that it was not a new species, but hitherto the mistaken description of it as $H$. toriu has not been corrected, as far as I am aware (cf. Stresemann, Sepik-Vögel, p. 38). H. macleayi is an inhabitant of Queensland, "Northern Territory," and parts of New South Wales. Mathews recognises several subspecies, which will be discussed elsewhere. As this species occurs also in the Louisiade and D'Entrecasteaux Islands, and on the south coast of British Papua northwards to Astrolabe Bay, there is no reason why it should not occur in New Britain; Stresemann suggests that all $H$. macleayi occurring out of Australia and its islands (Melville) might be migrants only, and this is probably the case.

The second bird described as new is Reinwardtoenas bleyi. This striking new bird was unfortunately already described as Henicophaps foersteri by Rothschild \& Hartert three years previously.

Probably new forms can still be discovered on the mountains and in the western parts of New Britain, though, of course, little can now remain unknown. Nests, eggs, and habits require still further investigation.

\section{Tringa hypoleucos $\mathrm{L}$.}

Common in March and April. Mostly moulting body plumage on underside.

\section{Tringa incana brevipes (Vieill.).}

ô ad. Talasea, 5.iii. 1925. Body plumage moulting.

\section{Numenius phaeopus variegatus (Scop.).}

3 s̊?. March and April. Moult on body plumage.

\section{Megapodius duperreyi eremita Hartl.}

Evidently common at Talasea, a series sent.

\section{Caloenas nicobarica nicobarica (L.).}

Eichhorn found this species common near Talasea and sent a series from January. Females, besides being smaller, with shorter neck-hackles, have the rump and upper tail-coverts more golden green. Dahl, who only found it on Credner Island, was wrong in saying it did not occur on New Britain, though it may now be absent from the inhabited parts of the Gazelle Peninsula, where he made his observations. A nest consisting of a few twigs was found on the butt of a fallen tree, $2 \mathrm{ft}$. from the ground, apparently empty. Another, containing one egg, on March 5, on the ground, about 1,500 ft. above sea-level. 
The egg is white with a faint creamy tinge without gloss and measures $42 \times 32 \mathrm{~mm}$. Lives, according to Eichhorn, mostly on the ground and is very shy.

\section{Ptilinopus superbus superbus (Temm.).}

Eichhorn did not find this species common at Talasea and sent only two males shot in January.

\section{Ptilinopus rivolii rivolii (Prévost \& Knip).}

See Nov. Zool. 1924, p. 198, 1925, p. 116.

As I said before, it was to be expected that this Pigeon occurred somewhere in New Britain, and this expectation has been fulfilled. Eichhorn found it common at Talasea and sent a series collected in January and February. The wings of the males measure $128-132 \mathrm{~mm}$. The iris is described as yellow, in one case reddish yellow, and once " dark," the latter possibly by an error or abnormal.

\section{Myristicivora bicolor subflavescens (Finsch).}

Eichhorn found this Pigeon apparently common in Talasea, for he sent 8 beautiful skins shot in February and March. The entire plumage to the base of the feathers is creamy yellow, deepest on head, neek, and underside; the shafts and outer webs of the lateral rectrices are quite bright chrome yellow. "White plumage tinged with yellowish" and "weiss, leicht gelblich getönt" are too mild expressions for these birds in fresh plumage, though it suits perfectly old specimens of ours collected by Webster and Curtis which were probably exposed to light when being dried, or are in old worn plumage. The freshly moulted bird collected by Eichhorn on Manus (Admiralty Is.) is like the New Britain ones. The Talasea birds are freshly moulted, some still in moult. The iris is described as brown, bill dull yellow, base and cere slaty blue, feet lead-blue.

I have no doubt that nowhere two forms of Myristicivora will be found breeding in the same area, and therefore believe that the above nomenclature will be correct, and that all Myristicivorae must be named trinomially, as subspecies of bicolor.

\section{Ducula (Globicera) rubricera (Bp.).}

Common at Talasea. Series from January and February. Some moulting on wings and tails, also a few feathers of the body plumage.

\section{Ducula finschii (Rams.).}

Carpophaga Finschii Ramsay, Journ. Linn. Soc., London, Zool. xvi, p. 129 (1881-locality not stated, but from New Ireland, teste Sharpe in Gould's B. New Guinea, pt. xvii).

Eichhorn found this species rare at Talasea, and sent only one pair shot January 30 and February 2. Both are moulting (body, wings, tail).

\section{Ducula melanochroa (Scl.).}

Cf. Nov. Zool. 1925, p. 117.

Eichhorn says these Pigeons are common when the figs are ripe, otherwise one does not see them, and that they do not occur below 1,500 ft. He sent 3 adults from Talasea, shot in January, which show moult on body plumage. 


\section{Gallicolumba beccarii johannae (Scl.).}

Cf. Nov. Zool. 1924, p. 198 (also Nov. Zool. 1925, pp. 118, 119).

Phlogoenas johannae Sclater, Proc. Zool. Soc. London, 1877, p. 112, pl. xvi (exact loc. doubtful, but in all probability Duke of York Island, which I designate as typical locality).

Gallicolumba beccarii nodifica Hartert, Nov. Zool. 1925, p. 118 (New Ireland).

In 1925 (p. 119) I said already that I believed this species " must and will be found in New Britain," where all the collecting had hitherto been done only in the Gazelle Peninsula. Now Eichhorn sent a fine series of 5 adult males and a female, shot in Talasea in March and April. The males vary in the colour of the chest, which in some is as dark as in our darkest specimens from New Ireland and Nissan and Feni Islands, in one as light as in a New Hanover bird, which agrees with the types in the British Museum. I therefore conclude that all the specimens from Dampier, New Britain, Duke of York, New Ireland, Feni, Nissan, and New Hanover are the same, and that my supposed nodifica (1.c.) cannot be separated; this also does away with the curious interrupted distribution which would result if nodifica was separable. From our examples from New Ireland it certainly seemed that they differed from the types, which have very white chests, nor did the Feni and Nissan series contradict this. The wings of the Talasea males measure 111-118 mm.

\section{Gallicolumba jobiensis (Meyer).}

Phlegoenas jobiensis A. B. Meyer, Mitth. Mus. Dresden, i, p. 10 (1875-Jobi).

Chalcophaps margarithae Salvadori \& Albertis, Ann. Mus. Civ. Genova, vii, p. 836 (1875-no exact locality given, but type from the coast near Hall Bay, S.E. New Guinea).

(Evidently Meyer's description of $P$. jobiensis appeared before that of C. margarithae, which came out in November, and therefore Salvadori adopted, in his great work, Orn. Pap., iii, p. 165, and elsewhere, Meyer's name, and it is strange that in the Cat. B. xxi he reverted to margarithae, which, in its first description, he spelt correctly with an $h$, while later on he used the Italian way of eliminating the $h$. Meyer's type was a young bird, but it has been carefully examined, and Salvadori himself said that there could be no doubt whatever that the name jobiensis referred to the same bird which he later on called margarithae.)

Eichhorn calls this species " comparatively rare and shy" near Talasea, but he sent 2 ad., 1 q ad., and 2 juv., shot in January, February, March, and April. "Iris dark brown, bill black, feet purplish red." Wings ô 148, 152, ㅇ $140 \mathrm{~mm}$. Young shot February and March badly moulting body plumage, wings, and tail.

\section{Henicophaps foersteri R. \& H.}

Henicophaps foerster Rothschild \& Hartert, Bull. B.O.Club, xix, p. 28 (1906-Massawa, New Britain), Nov. Zool. 1911, p. 168, pl. i.

Reinwardtoenas bleyi W. Meyer, Orn. Monatsjer. 1909, p. 36 (Toriu and Kambair, New Britain).

It is strange that this striking bird with its glossy wings was not discovered before 1905, as a good deal of collecting had been done in New Britain. Probably its real home is not in the Gazelle Peninsula, but in the main portion of the island. It seems that no specimens are known except the type in Tring, one in the Munich Museum, and the types of Father Meyer. Now Albert Eichhorn sent 2 males 
and 1 female, from Talasea, shot February, March, and April. He found it rare, mostly living on the ground. " Iris dark brown, bill blackish, distal part of lower light horn-colour, feet dull purplish red." The males have larger bills and are underneath nearly white, with a reddish-brown tinge on the crop. The female has a smaller bill, and the whole underside tinged with rusty brown. This shows that the type was also a female. Wings of the Talasea males 202, 203, of the female $197 \mathrm{~mm}$.

\section{Chalcophaps stephani stephani Rchb.}

Eichhorn found this Pigeon common, feeding on seeds off the ground. $\mathrm{He}$ sent a series shot from January to March. A young female in first plumage was shot January 21. Mostly in good plumage, but some February and March specimens moult on body, wings, or tail.

\section{Macropygia amboinensis carteretia Bp.}

Terra typica: New Ireland. Cf. Nov. Zool. 1925, p. 119.

Common near Talasea, fruit-eating (Eichhorn). Young and old from January to March, some moulting.

\section{Macropygia rufa rufocastanea Rams.}

Cf. anteà, p. 43.

Eichhorn found this species rare at Talasea and sent only one female shot May 1, 1925. My surmise that this species must occur on New Britain (anteà p. 43) has been fulfilled, though only one was obtained.

\section{Dupetor flavicollis nesophilus (Sharpe).}

Two beautiful males, March and April.

\section{Nycticorax caledonicus mandibularis Grant (?).}

Cf. Nov. Zool. 1914, p. 285, 1924, p. 199.

Rare at Talasea, feeding at night, according to Eichhorn. One adult female shot 7.iii.1925. Iris yellow. Wing 286, of a male shot on New Britain by Kleinschmidt 277, of one from New Hanover (Webster coll., not sexed) $283 \mathrm{~mm}$.

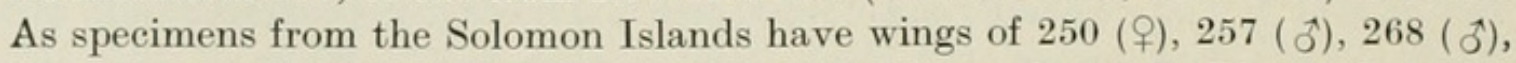
269 ( $($ ) , and 255 ( $($ ) , it seems that the Night Herons from the Bismarck Archipelago are a longer winged subspecies, but more measurements are required to confirm this! The long ornamental occipital plumes are white with a rufous tinge at base, tip, and outer webs, in the Talasea specimen.

\section{Henicopernis longicauda infuscatus Gurney.}

Henicopernis infuscata Gurney, Ibis, 1882, p. 128 (Blanche Bay, New Britain, type in Liverpool Museum, ex coll. Tristram).

Two specimens of this very rare bird were shot in January and February. Eichhorn says it was rare, only one other having been seen; one sees it among the tree tops and it feeds on tree-lizards, etc. Other birds take no notice of it, except the Drongos, 
I treat infuscatus as a subspecies of longicauda, because it has the essential features of the latter, the same markings of the head, the same markings of the wing-quills and rectrices; but it is a much smaller and blacker, somewhat "melanistic" form; the back and rump are black, but the scapulars show the same concealed greyish-brown bars as longicauda; the underside, which is creamy white, striped with black in longicauda, is black with white bases and whitish spots and edges to some of the feathers; under wing-coverts like the breast ; thighs pale brownish yellowish with blackish central longitudinal marks and a few whitish patches. "Iris bright yellow ; bill pale slate, or light horn, tip blackish ; feet dull bluish white."

Wings 우 340 , ô 355 , tail $255 \mathrm{~mm}$.

Stresemann has suggested that Henicopernis should not be separated from Pernis. Being a confirmed genus-lumper I should like to agree with him, but cannot go as far as that. The nostril in Pernis is an oblique slit, almost closed by an operculum, while in Henicopernis it is an almost perpendicular oval hole, the lores in Pernis are covered with the often described scale-like feathers-the most characteristic peculiarity of the Honey Buzzards-while in Henicopernis the lores are bare with a few isolated tiny apologies for feathers, nothing like the scaly feathers of Pernis.

Unfortunately - as of many Papuan birds - we know next to nothing of the habits and food of this, but Eichhorn says that $H$. $l$. infuscatus feeds on treelizards, which may, of course, be only one of its prey.

Hitherto this bird has always been called Henicopernis infuscata, but Pernis admittedly being masculine, Henicopernis must follow suit.

\section{Accipiter luteoschistaceus Rothsch. \& Hart.}

Accipiter luteoschistaceus Rothschild \& Hartert, Bull. B.O. Clu', xlvi, p. 53 (Jan. 1926-Talasea, New Britain).

This new Accipiter has the upperside dark slate-colour, the underside buff, on the chest, especially the sides, narrowly cross-barred, in one with brown, in the other with grey bars. Under wing-coverts uniform buff, primaries pale buff towards the base on the inner webs which have slaty-blackish cross-markings. Inner secondaries and scapulars towards the base chiefly white. Wings and tail outwardly like the back; rectrices on the inner webs towards the base buffish with slaty cross-bars. Wings 187 and 190, tail 139, 143, middle toe $28 \mathrm{~mm}$. "Bill black, feet dark or orange yellow." Cere not described on labels, but bright orange in the skins. Two males were shot at Talasea on March 12 and April 21, 1925.

This interesting new Accipiter is nearest allied to A. soloennsis ; in the latter, however, I have not seen such cross-barring on the chest; the tarsus in $A$. soloensis (in males) measures about 40 , in luteoschistaceus quite $50 \mathrm{~mm}$. The second primary in soloensis equals the fifth, in luteoschistaceus the seventh; the tip of the wing is much larger in soloensis, shorter in luteoschistaceus, in which the fourth and fifth (not the third and fourth) primaries are longest, the third and sixth only about $4 \mathrm{~mm}$. shorter-not 15 to $20 \mathrm{~mm}$. as in soloënsis. The bill is much larger in luteoschistaceus. Notwithstanding great similarity between the two birds (especially in the markings of the inner secondaries) it would be 
unjustifiable and rash to treat them as subspecies. Eichhorn says it was rare and not easily stalked.

\section{Accipiter novaehollandiae dampieri (Gurn.). ${ }^{1}$}

Urospizias dampieri Gurney, Ibis, 1882, p. 453 (New Britain). Accipiter hiogaster rooki Rothschild \& Hartert, Nov. Zool. 1914 . p. 288 (Rook Island).

In 1914 we had no good material from New Britain, while now we have received a wonderful series, 8 adult males and females from that island. This clearly proves that we were wrong in our conclusions in 1914, when we believed that the New Britain form was larger than the Rook Island birds. The males from New Britain have wings of 189-206, females of 219-232 mm., and the wings of the Rook males measure 192 and $195 \mathrm{~mm}$. (no females available). Thus Reichenow's of $\hat{o}$ 185-195, ㅇ 215-225 agree also quite well, but Gurney's of ô 209 , ㅇ 232-240 surpass our measurements.

It seems that a slightly larger (longer-winged) form is found on Manus and St. Matthias Island, as we measure males 200, 204, 212, and one female $237 \mathrm{~mm}$., but these differences are so variable and surpass ours from New Britain birds in the extremes only, that we (Lord Rothschild fully agrees with me in this case) do not venture to separate the birds from Manus and St. Matthias Island, unless at any future time larger series should show that the birds from these northern islands really reach larger measurements. The females from New Britain show all more or less obvious traces of whitish bars on the underside; the female from Manus is uniform, except for one white bar on one feather.

The iris is described by Eichhorn as dark brown, bill black, feet cadmium; the cere has obviously been yellow, and on one of the labels on a Rook Island bird it is described as yellow.

Eichhorn says it is common and lives on " birds, lizards, etc."

\section{Haliastur indus girrenera (Vieill.).}

Fairly common. One adult female and one juv. shot in March, both in partial moult.

\section{Baza subcristata bismarckii Sharpe.}

Three adults shot in February and March. The one from 10.ii and one of the March specimens moult wings, tail, and body plumage.

\section{Falco severus severus Horsf.}

An adult female Talasea 31.i.1925. "Iris dark brown. Bill black and slaty blue. Feet lemon yellow."

I am unable to separate this bird from typical severus. Cf. Nov. Zool. 1915 , pp. 49, 50 .

Eichhorn says it was "very rare." This Falcon seems to be rare on all

I I fully accept, as far as it goes, for the present the elassification of the species Accipiter fasciatus and Accipiter novaehollandiae, as proposed by Stresemann, Journ. f. Orn. 1925, p. 323. At first glance it seems very strange, but a study of these birds reveals the sense of this grouping. There are thus subspecies of $A$. novaehollandiae the following forms: rubianae, pulchellus, rufoschistaceus, bougainvillei, dampieri, misoriensis, leucosomus, cooktowni, novaehollandiae, griseogularis, obiensis, mortyi, pallidiceps, hiogaster, albiventris, polionotus, sylvestris, sumbaensis. 
islands where it occurs. This is the first we receive from the islands of the Bismarck Archipelago, where it has been recorded from New Britain and the Duke of York group only. Dahl only saw it once on New Britain, Heinroth did not come across it. In all the collections from the Solomon Islands we received it only once; even on the Sunda Islands it seems to be rare. It is a true "Hobby." The food consists chiefly or entirely of insects.

\section{Ninox odiosa Scl.}

Ninox odiosa Sclater, Proc. Zool. Soc. London, 1877, p. 108 (New Britain, Brown coll., type in Brit. Mus.).

This Owl is only known from New Britain, where it does not seem to be rare, having been collected on the Gazelle Peninsula by Brown, Kleinschmidt, Finsch, Kubary, Dahl, and Heinroth.

Eichhorn found it at Talasea and sent 4 adults from February, March, and April. He says they have a long continuous call, sometimes lasting three minutes. He found the iris bright yellow, bill slaty, tip and culmen greenish yellow. Wing ô 178, 183, 187, 171, $174 \mathrm{~mm}$.

There is no known ally of $N$. odiosa in the Papuan fauna but the Celebes N. punctulata; the latter, however, differs in having on the abdomen cross-bars or spots, instead of shaft-lines or sagittate markings, in having the tarsus feathered a little more down to the toes, no large white spots on the wing-coverts and scapulars, and in having the iris dark chestnut or chocolate brown, instead of bright yellow.

\section{Cacatoes galerita ophthalmica (Scl.).}

Cacatua ophthalmica Sclater, Proc. Zool. Soc. London, 1864, pp. 188, 189 ("Solomon Islands," errore! Terra typica New Britain !).

Only known from New Britain! Differs from C. g. triton in the shorter crest, composed of wider and not upturned (convex), but slightly concave feathers, if viewed from above; in both forms the colour of the naked ring around the eyes is described as blue, but in all our skins of "triton" it is dried yellowish, while in the ophthalmica it appears slate, more or less spotted with yellowish. Iris brown. Bill and feet slaty black. Wings ô 283-300, † 273-289 $\mathrm{mm}$. Eichhorn found it rather common and sent a fine series. It is one of the most interesting birds of New Britain, showing that this island, by far the richest in species in the Bismarck Archipelago, has more Papuan elements than the other islands, and the farther the latter are removed from New Guinea the poorer they are in species.

\section{Micropsitta pusio pusio (Sel.).}

Nasiterna pusio Sclater, Proc. Zool. Soc. London, 1865, p. 620, pl. 35 (substituted type locality: Duke of York Is. The originally given locality "Solomon Islands" of çourse incorrect).

For a long time I have wished for fresh material of typical pusio, and at last have received 4 New Britain specimens, 3 males and 1 female. These clearly show that our M. p. salvadorii is well distinguishable by its more or less yellow superciliary stripe, but I now consider that this form ranges from the Weylandt Mountains and the Mamberano River along the north coast of Papua, including the Vulcan and Dampier Islands, and extends southwards to S.E. New Guinea : 
Milne Bay, Aroa River, Kumusi River. Three rather poor specimens, one quite young, from Fergusson Island, D'Entrecasteaux group, may belong to a different subspecies, more like $M$. pusio pusio, but perhaps darker green on the underside.

Unfortunately I have not seen the type of $M$. beccarii. It is from Wairor on the west coast of Geelvink Bay, almost opposite Ron Island, but a little farther north; another specimen from Wandammen was considered the same by Salvadori; we have three, unfortunately very bad specimens, a male and 2 females, from the little island of Ron in Geelvink Bay, close to Wandammen and not far from Wairor, which, one should think, would be beccarii, but the description (and the figure in Gould's Birds of New Guinea) does not agree ; our Ron specimens, collected by William Doherty, have the sides of the occiput yellowish, like salvadorii, and certainly not "brunneo-olivaceis" as described by Salvadori.

A specimen (not sexed), collected by A. S. Anthony in the Owen Stanley Mts. ("Kotoi district"), already mentioned, Nov. ZooL., 1901, p. 81, under " Nasiterna pusio," is so brightly coloured, that it is not impossible that it forms a separate mountain subspecies, and future collectors in that district should try to obtain a series.

The Micropsitta from St. Aignan and Sudest Island in the Louisiade group, which we formerly united with $M$. pusio pusio (of which we had no adequate material), are almost exactly like the birds from S.E. New Guinea which we now consider to belong to salvadorii, but have much longer wings.

Wings from New Guinea measure 60 (ㅇ) to $65\left(\delta^{1}\right)$, rarely 66 , once 68 . Twenty-five measured.

Wings in the Sudest and St. Aignan specimens from 64 and 65 (f) to 69-70 (ठิ). Eighteen measured.

I therefore propose to call the long-winged Louisiade subspecies

\section{Micropsitta pusio stresemanni subsp. nov.}

Type: $\hat{o}$ ad. Mt. Riu or Rattlesnake, Sudest I., 8.iv.1916. No. 7343, A. S. Meek coll.

Eichhorn found this little Parrot somewhat rare at Talasea. Three of the specimens were shot in February, one in April. Wings 59-61 mm. Two February specimens moult on the tail. These birds, according to Eichhorn, build their nests in white ants' nests ; on St. Matthias Island a nest with young of Micropsitta meeki proxima was found not more than 9 inches from the ground.

My friend Stresemann described the pusio from Finschhafen (Kai Peninsula) as Micropsitta pusio rothschildi (Archiv f. Naturg., 89A, Heft 7 \& 8, 1923), correctly stating how it differs from $M . p$. pusio, except that he did not mention the yellowish colour on the supercilium and sides of the occiput, which is the characteristic difference of $M . p$. salvadorii. He kindly sent me the type-specimens, and I am sorry to say I cannot separate these birds from our series from S.E. New Guinea which in my opinion should be united with our $M$. pusio salvadorii. If the series is laid out it seems as if the specimens from the Ambernoh River and Humboldt Bay, together with those from the Kai Peninsula (Finschhafen and Bassa Bay), have the underside more yellowish, but this is a rather variable character, some from S.E. Papua being equally yellow, while the Vulcan Island ones are greener again than the Finschhafen and other north coast examples. 
I am therefore afraid that all the birds from the Ambernoh River and Takar and Weylandt Mountains to S.E. Papua, including Stresemann's rothschildi, must be united-and it remains to be confirmed if they differ well from beccarii.

29. Charmosynopsis placentis pallidior R. \& H.

Cf. Nov. Zool. 1924, p. 201.

Common at Talasea. February and March specimens sent.

\section{Lorius roratus goodsoni Hart.}

Lorius roratus goodsoni Hartert, Nov. Zool. 1924, p. 123 (Manus); ef. t.c. p. 203, 1925, p. 125, and anteà,

The series of $4 \hat{\sigma}$ and $5 q$ from Talasea is not distinguishable from Manus specimens, except that the bills of several of the females and one male are smaller, thus showing a tendency towands $L$. r. solomonensis.

The wings of the males measure 240-255 mm, exactly as our Manus specimens, while the females have wings of 222 to $241 \mathrm{~mm}$. (230-240 on Manus).

Eichhorn found this Parrot very common and a pest of the gardens; he says they even attack the taro in the ground; nests in hollow trees.

\section{Domicella hypoinochroa devittata (Hart.).}

Cf. Nov. Zool. 1898, p. 530, 1924, p. 201, 1925, p. 122.

This common Parrot was frequent at Talasea. A series sent from January : half of them moult the wing-feathers, a few the tails and their coverts. Two specimens have the black bars on the under wing, which are as a rule absent in $D$. h. devittata; one of them is quite young, the other is older, but also juvenile ; apparently the black bar is an ancestral character, still present in young and very exceptionally indicated in old birds.

\section{Geoffroyus heteroclitus (Hombron et Jacq.).}

Cf. Nov. Zool. 1924, p. 201.

Eichhorn found this species common at Talasea. He says " that their call, while in flight, has an aeolian sound," and that, like other Parrots, they live on fruit and make their nest-holes in rotten trees. He sent a series, shot in January, February, and April. They are mostly in good fresh plumage. A juvenile male, shot January 26, moults wings and body plumage; the crown is blue-grey mixed with yellow, the coming feathers being yellow.

\section{Trichoglossus haematodes aberrans Rehw.}

Cf. Nov. Zool. 1925, p. 123.

Two from February, one April. One female has much narrower dark edges to the feathers of the breast than the other female and a male; the narrow edges, however, are worn off. The two February specimens moult wings, tail, and body plumage, the April one tail and breast.

Eichhorn found it not rare, and says it eats " honey," by which evidently nectar is meant. 


\section{Halcyon chloris tristrami Layard.}

Halcyon tristrami Layard, I is, 1880, p. 460, pl. xv ("Makira harbour, we believe." Evidently the belief that this bird came from Makira harbour, on the island of San Christoval, was erroneous, as the description and figure are certainly not taken from San Christoval specimens, but agree best with New Britain ones, and the types in the Tristram collection, now in Liverpool, are marked as coming from Blanche Bay, New Britain. Therefore Blanche Bay, New Britain, should be regarded as the typical locality of H.tristrami. See Nov. Zool. 1905, p. 256 !).

We have at last received a series of eight real tristrami from New Britain ; these, in connection with the fine material of other forms of the tristrami group of these Kingfishers, enable me to review the various forms profitably. In opposition to my former views I now treat them as subspecies of Halcyon chloris. The belief that two forms of $H$. tristrami and chloris were found in one and the same locality was evidently due to the insufficient material formerly available, and the misleading conception of these birds in the Cat. B. Brit. Mus., xvii. Cf. Nov. ZooL., 1925, pp. 125-127.

\section{(1) Halcyon chloris tristrami Layard.}

Terra typica New Britain. See above!

Abdomen bright rufous, gradually paling off to almost white on the throat, sometimes paler from having a white patch in the middle of the abdomen, but flanks and under wing-coverts remain always rufous. Possibly the birds from the Gazelle Peninsula have longer wings, measuring 106-111, once $116 \mathrm{~mm}$, while those from Ta'asea are all 105-107 mm. long. (Two specimens from Fauro in the Solomon group, with wings of 105 and $107 \mathrm{~mm}$., are indistinguishable from tristrami, but must belong to alberti. All statements of occurrences elsewhere than on New Britain will be wrong; in the Solomon Islands represented by alberti-if separable-and solomonis.)

(2) Halcyon chloris alberti R. \& H.

Halcyon tristrami al herti Rothschild \& Hartert, Nov. Zool. 1905, p. 256 (type: Kulambangra !).

Inhabits Kulambangra, Rendova, Vella Lavella, Guadaleanar, Isabel, Gizo, Bougainville-and must also be the Fauro form. Twenty-nine specimens before me.

This form is a very close ally of H. c. tristrami; when it was described we did not understand its variability and how close it is to tristrami. It might by some ornithologists be united with tristrami, but crown and wings are deeper blackish and blue, and the rump is deeper blue than in any tristrami we have, i.e. our 8 from Talasea and 2 from the Gazelle Peninsula received in exchange from Berlin; strange to say the two Fauro specimens have the rump as pale as in the New Britain tristrami.

Wings 102-111, mostly 104-108 mm.

\section{(3) Halcyon chloris solomonis Rams.}

Halcyon solomonis Ramsay, Proc. Linn. Soc. N.S. Wales, vi, p. 833 (1882-no locality stated, but in

Proc. Linn. Soc. N.S. Wales, vii, p. 21, Ugi and St. Christoval are said to be the localities, and

the distinctive characters are very well stated). Nov. Zool. 1925, p. 126.

Halcyon perplexa Rothschild \& Hartert, Nov. Zool. 1908, p. 361 (San Christoval).

Seems to be restricted to the island of San Christoval, Solomon group, and its satellites (Ugi, and perhaps others). 
Very easily distinguished from the forms mentioned above. Very much smaller, wings 93-95 mm. No concealed white patch on the nape! Upperside of a different, somewhat lighter blue. Underside white, but sides of body and a large patch on sides of breast cinnamon, nearly forming a band across the breast. Lores, small patch behind eye (which is not found in tristrami and alberti!), and nuchal collar cinnamon, but in some specimens white, also without cinnamon on underside.

Though this form is sc very different I have no doubt that it is a subspecies of chloris. I explained before that this form was already described in vol. vi of the Proc. Linn. Soc. N.S. Wales, and that perplexa is a synonym !

\section{(4) Halcyon chloris nusae Heinr.}

Halcyon nusae Heinroth, Journ. f. Orn. 1902, p. 437, pl. viii. fig. 2 (Nusa and other small islands and New Hanover, and near north coast of New Hanover); Nov. Zool. 1924, p. 205, 1926, p. 38.

Common on New Hanover and Feni Island, the small islands between New Hanover and New Ireland-probably also parts of New Ireland, but in the $\mathrm{S} . \mathrm{W}$. part it is represented by $H$. c. novaehiberniae.

The white patch on the occiput is present again and often more developed and less concealed; differs from tristrami chiefly in the blackish and sometimes dull greenish (less bluish) black crown. Upper back, scapulars, and upper wingcoverts darker, more greenish; underside and nuchal collar white, the latter sometimes buff or light cinnamon, in which cases there is also a pale cinnamon patch on the sides of the chest.

Wings 105-110, once (a Feni specimen) $115 \mathrm{~mm}$.

\section{(5) Halcyon chloris novaehiberniae Hart.}

Halcyon tristrami novaehiberniae Hartert, Nov. Zool. xxxii, p. 125 (1925-S.W. New Ireland).

Only known from south-western New Ireland.

Differs from tristrami in having shorter wings, 102-107 mm., underside, lores, and collar white, with or without a faint buff tinge, bill shorter : $35-39 \mathrm{~mm}$. from end of frontal feathering.

Differs from nusae in having the wing shorter, the nuchal white patch apparently not larger than in tristrami, the scapular bluer, rump of a somewhat deeper blue.

\section{(6) Halcyon chloris stresemanni Laubm.}

Halcyon chloris stresemanni Laubmann, Verh. Orn. Ges. Bayern, xv, p. 391 (1923-"Französische Inseln im Bismarck-Archipel ").

Very near to novaehiberniae, but wings 107-110, bill larger ! Crown of head not so black as is freshly plumaged adult nusae, wings, rump, outside of quills and tail deeper blue! Underside white, but lower abdomen light cinnamon, gradually whitening towards the breast; nuchal band white or white. So far only known from the French Islands (Witu), but a specimen from Rook Island, which Rothschild and I, Nov. Zool., 1914, p. 212, called "Halcyon tristrami tristrami," is indistinguishable from our series from Witu.

Eichhorn found the H.c. tristrami common at Talasea and says that it makes a nest hole high up in rotten tree trunks. The specimens he sent were shot in February and March. Some March specimens are in badly worn 
plumages and moult body plumage, 2 also tails and 1 primaries ; on the breast fresh-coming feathers are considerably darker cinnamon than the old faded worn ones.

Halcyon pachyrhynchus Rehw., Orn. Monatsber. 1898, p. 48, from New Britain, is, of course, the young tristrami. This was known to Reichenow in 1899, as he placed the name correctly in the synonymy of $H$.c. tristrami, and it would perhaps not have been necessary to repeat it here, if in the description it had not been compared with $H$. vagans, or more correctly Halcyon chloris sanctus from far-away New Zealand.

\section{Halcyon albonotata Rams.}

Halcyon al onotata Ramsay, Proc. Linn. Soc. N.S. Wales, 1884, p. 863 (New Britain).

This very rare bird was found by no means common, but Eichhorn managed to get 7 specimens at Talasea, in February, March, and April ; he says it makes its nests in white ants' nests on trunks of trees. The iris is dark brown, bill black, feet black; one female has some whitish colour on the under mandible.

The male has the back white from the upper back to the tail-coverts inclusive; in the female only the upper back is white, the lower back and rump are purplish blue, these purplish blue feathers reaching over the short white upper tail-coverts. Under surface entirely white in both sexes. Wings ô 82-85, ㅇ $82-82.5 \mathrm{~mm}$. On both sides of the forehead, just behind the nostrils, is a white spot. The erown is rich blue, on the sides lighter and more ultramarine; a black (not blue !) band from the lores over the ear-coverts and narrowly encircling the blue crown. Scapulars and wing-coverts deep purplish blue, rather different from the crown. A more or less concealed white patch on the nape. Under wing-coverts white, on the under primary coverts a small dusky patch, varying in size.

The nearest ally is Halcyon leucopygia from the Solomon Islands, in which the sexes differ in the same way. In the latter, however, the crown is of the same colour as the scapulars, there are no white spots on the forehead, and there is on each side of the rump a reddish-lilac patch; this colour also covers the under tail-coverts, which are white in $H$. albonotata; H. leucopygia is also somewhat larger.

(Halycon toriu Meyer, Orn. Monatsber. 1909, p. 34, from the Toriu River in the Gazelle Halbinse1, New Britain, is H. macleayi.)

\section{Halcyon sancta sancta Vig. \& Horsf.}

This winter-visitor from Australia was found common in April and May. Most of the specimens sent are moulting, some in April already in beautiful fresh plumage, others in quite worn old garb, some juvenile.

\section{Tanysiptera sylvia nigriceps Scl.}

(Tanysiptera sylvia sylvia from Australia and T. sylvia salvadorina from New Guinea are closely ailied; if only subspecies the New Britain form must be called T. sylvia nigriceps; the latter has the crown black, the other two blue; sylvia has the upperside blue, while in nigriceps and salvadorina only the wings are blue, and in salvadorina the patch on the interscapulium is brownish buff, but fades considerably in worn plumage.)

Tanysiptera nigriceps Sclater, Proc. Zool. Soc. London, 1877, p. 105 (Duke of York Is.).

Eichhorn sent a fine series of 11 of this species, shot from January to March. February 18 and March 23, young birds were shot. The sexes are perfectly 
similar; the tails vary in length, but not according to sex. The longest middle rectrices I measure 175 ; the shortest, in a full-grown male, $145 \mathrm{~mm}$. The iris is marked as dark brown, bill deep red, feet dull yellowish, dull greenish yellow, one dull reddish yellow. In the young the bill is brown, the under mandible only yellowish. In the young the feathers of the crown are black as in the adult, but those of the nape and a line from above the eyes have blue tips. The patch on the interscapular region is buff, or pale rufous brown; in the adults this patch is white, but generally with a faint buff tinge in front. The outer webs of the elongated rectrices are blue, the inner ones white, while in T. sylvia leucura Neum., from Rook Island, all rectrices are perfectly white in fully adult birds.

Eichhorn found this Tanysiptera fairly common at Talasea.

(With other birds supposed to have been collected on New Ireland we received many years ago a $T$. s. nigriceps, but as nobody else has found it there, and it was not labelled, this locality cannot be credited; while in that collection were mostly undoubted New Ireland specimens, a few others in it were obviously not from there.)

\section{Ceyx lepida sacerdotis Rams.}

Ceyx sacerdotis Ramsay, Journ. Linn. Soc. London, Zool. xvi. p. 128 (1822-New Britain).

Eichhorn sent a very welcome series of 10 specimens from the Talasea district. We possessied only a bad skin collected by Heinroth and 7 from Rook Island. The latter, shot in July and August, are in magnificent fresh plumage, while the Talasea ones, collected from January to April, are more or less worn and some begin to moult. It seems for this reason that the shining ultramarine spots to the tips of the feathers of the crown are larger in the Rook examples, smaller in the Talasea ones, in which they are worn down. The Talasea birds range not quite so large as the Rook examples; while on Rook Island the wings measure 60-65 (the latter only once), in the Talasea ones they are $60-61$, in the one from Ralum $61 \mathrm{~mm}$. Also the bills on Rook Island range from 32-35 (measured from the nostril), on New Britain 30-32.5 mm. I do not venture to separate the Rook form for this reason, as larger series might show that these differences are not constant.

I have already (Nov. Zool. 1914, p. 213) shown that only the lower mandible can be described as "red," the upper being brown or blackish; in the Cat. B., xvii, p. 184, Sharpe described the Solomon Islands form which Rothschild \& Hartert named Ceyx lepida collectoris.

Eichhorn says these birds were not common and made their nests in the form of holes in a bank, also that they lived in the scrub, not on water.

\section{Alcedo atthis pelagica Stres.}

One pair sent.

Eichhorn found them inhabiting rivers, creeks, or mangrove swamps, and says they tunnel a hole, about 15 inches deep, in a bank, and that they live on fish. 


\section{Scythrops novaehollandiae Lath.}

Scythrops novaehollandiae Latham, Index Orn. i, p. 141 (1790-near Sydney, N.S. Wales).

Eichhorn sent 2 males, one with a much smaller bill than the other. $\mathrm{He}$ saw very few, generally with 2 crows in hot pursuit. It is known (Otto Meyer, P. Schumm) that the crow is the foster-parent in New Britain-as it is in Australia. Mathews separated a western subspecies, but it does not seem to be tenable. Eichhorn marked the eye as dark red.

\section{Cuculus optatus Gould.}

Cuculus optatus Gould, Proc. Zool. Soc. London, 1845, p. 18 ("Port Essington, Australia ").

Three adults, all three marked as males, 12.i.1925 and 10.ii.1925. The two February specimens moult their body plumage. Of course migrants from Siberia or North China, etc.

\section{Eudynamis scolopacea salvadorii Hart.}

Eudymamis orientalis salvadorii Hartert, Nov. Zool. 1900, p. 232 ("New Britain and New Ireland").

(A specimen said to be from New Ireland, which came with many other New Ireland birds, was made the type ; as, however, nobody else seems to have got this bird from New Ireland, it is possible that the type had come from Duke of York Is., or New Britain.)

Three males from March, one female from April ; they are quite typical. The wings of the males measure 207 and 217 , one is moulting, $+214 \mathrm{~mm}$. Iris males bright red, $q$ dark reddish brown ; bill males slaty blue, female dull bluish grey and black; feet slate.

Eichhorn says it is " common."

\section{Cacomantis variolosus macrocercus Stres.}

Nov. Zool. 1925, pp. 127, 168 .

Eichhorn sent a fine series of 8 adult and 1 juv., all marked as males. Their wings measure $119,125,126$ (three times), and 130 (twice) $\mathrm{mm}$. One is moulting on the outer primaries. Under tail-coverts chestnut-rufous in all, under-surface grey, belly more or less rufous, abdomen grey, in most specimens with a varying amount of rufous tinge. Under wing-coverts light chestnut-rufous to pale rufous, "Iris brown; bill black, base of mandible brown, feet dull yellow and brown, or brownish yellow."

A young in first plumage was shot April 27.

Eichhorn says it is common and feeds on caterpillars.

\section{Chalcites lucidus lucidus (Gm.).}

Cf. Nov. Zool. 1925, p. 159.

1 ô, 2 우. Talasea 28, 29.iv. 1925.

Eichhorn says it seems to be migratory. It is indeed a winter visitor from New Zealand. 


\section{Centropus ateralbus Less.}

Nov. Zool. 1925, p. 127 ; Bull. B.O. Club, xlvi, p. 50 (January 1926).

Eichhorn sent a remarkable series of 19 skins in many different colorations. Lord Rothschild has described these variations in Bull. B.O. Club, xlvi, and I have mentioned some in Nov. ZooL. xxxii.

The "normal" plumage is undoubtedly blue-black, throat, chest, and a wide ring round the neck buffy white-also most of the primary coverts white, and this white patch occurs in all varieties, even if the white on throat, chest, and neck is replaced by black, though in that case single whitish feathers are usually seen irregularly here and there. In the series from New Britain are a number of brownish white and pearl-grey specimens, described by Lord Rothschild, l.c. Among the whitish-grey specimens is a young in first plumage. The iris of adults is dark red (in one case marked as dark brown), in young birds brown or bluish grey. The bill is black in adults, under mandible and tip of upper light horn-brown in young birds.

Eichhorn found the species common, living, as described by Dahl, from the ground to the highest trees, from which they "plane" down.

\section{Centropus violaceus Quoy et Gaim.}

Nov. Zool. 1925, p. 127.

Eichhorn sent a series of 8 adults, mostly males. The females don't appear to differ from the males. The iris is red (" dark red," "bright red "), bill black, feet " dull white, whitish slate, slaty bluish." The tails of all these are shorter than in the one we had from New Ireland (typical locality), which has a tail of $410 \mathrm{~mm}$., while the tails of the Talasea birds measure (full-grown ones only measured) $320,330,325,350,350,365 \mathrm{~mm}$., females not smaller; wings 253 , $253,256,275,285 \mathrm{~mm}$. It is therefore possible that the New Ireland form has a longer tail, in which case the one from New Britain must receive a new name.

Eichhorn calls it " uncommon but not rare," and says that it frequents places thick with vines or twining ferns, and that they "work up to the top of the trees, and then plane down," exactly as it is described of Centropus ateralbus. Mostly seen in pairs, timid, loud booming call, bad fliers.

The specimens were shot January to April; most of them show moulting feathers in tail and wings.

\section{Eurystomus orientalis crassirostris Scl.}

Eurystomus crassirostris Sclater, Proc. Zool. Soc. London, 1869, p. 121 (Solomon Is., errore, terra typica New Britain-cf. Nov. Zool. 1903, p. 197).

Five specimens, January, February, and April.

So far, I have found the differences between crassirostris neohanoveranus (sic) and solomonensis quite good, but an adult female (No. 9675) from Talasea, shot January 12, has an (? abnormally) large bill, with a very small black tip and the purplish-blue forehead of neohanoveranus. As 3 of the others have the upper bill (maxilla) mostly blackish, we cannot say that we have an adequate series from New Britain. If No. 9675 is a normal adult, the New Britain form (crassirostris) would not differ from neohanoveranus, except by the black tips to the maxilla, which is, however, sometimes found in New Hanover! In our large 
series of supposed crassirostris from New Guinea I have not found one with a bill so large as in No. 9675, nor one with a purplish forehead. The other specimens from New Britain can, however, not be satisfactorily separated from the Papuan series. Is now the No. 9675 a stray bird from New Hanover? Hardly possible, as from the French Islands we received what we call typical crassirostris, like the Papuan birds.

\section{Merops ornatus Lath.}

A series from end of March and April, some in juvenile plumage.

Eichhorn finds this Australian bee-eater common on the coast. He says they arrive end of March and in April, and leave New Britain in September and October, that is, at the end of the north-west and by the end of the south-east monsoon respectively; they have special roosting-trees.-There is no proof whatever that they ever nest on these islands! April specimens begin to moult, but an adult male from March 31 has already fully moulted middle rectrices.

\section{Caprimulgus macrurus albolaxatus R. \& H.}

Caprimulgus macrurus albolaxatus Rothschild \& Hartert, Nov. Zool. 1918, p. 323 (New Britain to Vulcan Island, type Vulcan Island); Stresemann, Archivf. Naturg. 89, Abt. A, 7. and 8. Heft, 1923.

Two males from Talasea, May 1925. The white on the inner web of the first primary keeps about 2 to $2.5 \mathrm{~mm}$. away from the shaft, the white on the outer tail-feathers is 55 and $60 \mathrm{~mm}$. long. This subspecies is, I am afraid, only recognisable in series; single specimens are apparently not always very distinct.

Eichhorn says he found it in the low country on the coast.

\section{Hemiprocne mystacea aeroplanes Stres.}

Hemiprocne mystacea aeroplanes Stresemann, Anzeiger Orn. Ges. Bayern, No. 5, p. 38 (1921-New Britain, type Blanche Bay).

A series from January and February, when they were not rare. Wing ô $209-215$, ㅇ 210-217, but once $225 \mathrm{~mm}$. !

\section{Collocalia francica reichenowi Stres.}

Cf. Nov. Zool. 1925, p. 128.

1 q ad. Talasea 28 .iv. 1925.

This specimen agrees with our 3 skins from New Ireland, and I think now that it is the same as the Guadaleanar (Solomon Is.) one. These birds are very much like C.f. eichhorni from St. Matthias Island (Nov. ZooL. 1924, p. 269), but in the series the back is slightly darker, less brownish, while the bar across the rump is more brownish in reichenowi, somewhat whiter in eichhorni.

Eichhorn says it was common, but sent only one female.

\section{Pitta macklotii gazellae Neum.}

[Pitta Macklotii Temminck, Pl. Col. 537 (1834 type from Lobo, New Guinea, Salomon Müller coll.).] Pitta mackloti gazellae Neumann, Orn. Monatsber. 1908, p. 27 ("Gazelle-Halbinsel Neu Pommern," i.e. N.E. New Britain). Cf. Nov. Zool. 1914, p. 213.

A very fine series of 7 adults and 1 jun., with throat still partly whitish, lower abdomen brown. "Iris brown, light brown, or dark brown. Bill black. 
Feet pale slaty blue." In the young bird the mandible is brownish-horn colour. All collected January to March.

Eichhorn says that one seldom sees these birds unless one whistles them up. Nest a ball of leaves on the ground. The native name is Ruk. It lives entirely on the ground, feeding on insects, larvae, etc, but ants are not recorded by any observer. Otto Meyer found eggs in June, September, December, and February.

\section{Hirundo tahitica frontalis Quoy et Gaim.}

Hirundo frontalis Quoy et Gaimard, Voy. Astrolabe, Zool. i, p. 204, pl. xii, fig. 1 (1830-Dorey, New Guinea); ef. Oberholser, Bull. 86, U.S. Nat. Mus. 1917, p. 33, Stresemann, Sepik article, p. 25.

It seems to me certain that a Papuan race, extending from New Guinea to New Britain and the D'Entrecasteaux Islands, must be distinguished from $H$. tahitica javanica, the red on face and throat being slightly paler, underside as a rule less dark, wing generally longer. It is strange that both frontalis (recorded as javanica) and tahitica have been obtained in New Britain, but probably only the former is breeding there, and $H$. tahitica tahitica is a visitor. I therefore follow provisionally the arrangement proposed by Stresemann.

Only a single male was sent from Talasea, where Eichhorn found the species rare ; shot March 6, 1925. It has just completed its moult, outermost primary still growing.

\section{Monarcha alecto chalybeocephalus (Garnot).}

[Drymophila alecto Temminck, Pl. Col. 430, fig. 1 (1827- "Celebes," errore ! Terra typica Ternate, ef. Nov. Zool. 1918, p. 315.]

Muscicapa chalybeocephalus Garnot, Voy. Coquille, i. 2, p. 589, pl. 15 (1829-Port Praslin, South New Ireland).

Adult males, adult females, and 2 juv., January to March. The females of course have the upperside of the head glossy green-black, the underside white with a faint rusty tinge on the belly, mandible and maxilla dark. The younger female has a certain amount of rust-colour on the breast, sides, and abdomen, and part of the mandible bluish.

Eichhorn found this species common on the coast, and saw it at 1,200 ft. elevation.

\section{Monarcha hebetior eichhorni Hart.}

Monarcha hebetior eichhorni Hartert, Nov. Zool. 1924, p. 271, 1925, p. 129 (New Ireland).

4 ô ad., 3 o ad., Talasea, January and February 1925.

"Iris dark brown, bill black and chalky blue, feet black." The bill seems to be blue, with tip and lower mandible black. Wings ô 81-86, 우 77-77.5 mm.

Eichhorn says that in New Britain this is a mountain species, not occurring on the coast, and that the call is the same as that of $M$. a. chalybeocephalus.

The various forms of blue-black Monarcha from these islands may be described as follows :

Monarcha alecto chalybeocephalus.- $\hat{\sigma}$ ad. Steel-blue, feathers of crown longer. $q$ ad. Top of head greenish steel-blue, underside pure white.

Monarcha hebetior hebetior.- $\hat{\sigma}$ ad. Darker, more blue-black, feathers of crown shorter. Wings $60-62 \mathrm{~mm}$. क ad. Top of head blue-black, underside 
white with a greyish tinge, the black bases of the feathers extending further. Wings 57, $60 \mathrm{~mm}$.

Monarcha hebetior eichhorni.- $\hat{o}$ ad. Still darker, more deep blue-black, feathers of crown slightly longer than in hebetior, shorter than in chalybeocephalus. Wings 81-86. $q$ ad. Top of head dark ashy grey, underside ashy grey, middle of abdomen whitish. Wing $75-77.5 \mathrm{~mm}$.

\section{Monarcha verticalis Scl.}

Cf. Nov. Zool. 1914, p. 214, 1924, p. 207, 1925, p. 129.

Eichhorn sent a series of adult males and females and one young, all shot in February.

It seems as if the white of the rump is more extended in the specimens from New Ireland and New Hanover, but as this is also the case in the birds from Rook Island, and as it is rather variable, I am of opinion that it is not a local character. One of the two females sent from Talasea has no pure white on the rump, and the other not very much. Females from other islands, however, are not distinguishable from males, and they must be correctly sexed, as it is not conceivable that we should never have received a female before. One female has small white spots to the tips of 3 of the throat feathers. Two perfectly adult males from New Hanover, one from Rook Island, and one from Talasea have small white spots to the outer or inner webs of the lateral rectrices.

\section{Rhipidura tricolor melaleuca (Quoy et Gaimard).}

Cf. Nov. Zool. 1914, p. 215, 1925, p. 130.

Eichhorn found this flycatcher common on coastal flats and sent a series collected in February, March, and April, mostly moulting primaries.

\section{Rhipidura rufiventris finschii Salvad.}

Rhipidura finschii Salvadori, Orn. Pap. iii, p. 532 (New Britain).

(Cf. Rhipidura rufiventris setosa, etc., Nov. Zool. 1925, p. 130.)

Eichhorn found this bird common at Talasea and sent a series, all shot in January. This is a very distinct subspecies. Wings ô $84-90$, ㅇ $78 \cdot 5-79 \mathrm{~mm}$.

\section{Rhipidura dahli dahli Rehw.}

Rhipidura dahli Reichenow, Orn. Monatsber. 1897, p. 7 (Ralum, New Britain); id. Mitteil. Zool. Samml. Berlin, i, p. 88, pl. ii, fig. 2 (1899-Ralum); Hartert, Nov. Zool. 1925, p. 130.

It is strange that this bird was not discovered before by Kleinschmidt, Finsch, and other collectors, and that it was left to Dahl to make it known for the first time. It does not seem to be particularly rare and Rhipidurae are somewhat conspicuous birds. Eichhorn found it fairly common at Talasea and sent 8 skins, one shot January 27, the others in February and March.

These specimens agree very well with each other. All the tail-feathers have a large black patch before the tip ; these black patches are largest on the middle pair of rectrices where they vary in length from 30 to $38 \mathrm{~mm}$., and they are slaty black and clearly visible both above and below. The top of the head, lores, and far-coverts are dusky brown, or a sort of umber brown. The wings measure o $67-68$, q apparently much shorter, but both moulting ! 
In Nov. ZooL. 1925, p. 131, I said already that a series of males from New Ireland and New Britain might show differences; this is indeed the case, and I am obliged to name the subspecies from New Ireland, and propose for it the name

\section{Rhipidura dahli antonii subsp. nov.}

in honour of Anton Reichenow, whose work on the birds of the Bismarckinseln is of the utmost value and usefulness to me during my studies of the birds of these islands; as there is already a Rhipidura reichenowi Finsch from Babber (a very distinct subspecies of rufifrons), I name it by Reichenow's Christian name.

Rhipidura dahli antonii differs from $R$. dahli dahli as follows :

The blackish patches on the rectrices are less in extent, in none of our 6 specimens more than $19 \mathrm{~mm}$. long.; they get much smaller and disappear entirely on the lateral pairs, and are not visible from underneath, also they are more greyish, not so dark. The lores and ear-coverts are darker. In the New Ireland form the tip of the middle rectrices is at least a centimetre wide, in $R$. dahli dahli only a few mm., and sometimes the black extends quite to the tip. Type of R. dahli antonii: $\widehat{\jmath}$ ad. New Ireland, 18.i.1924. No. 8975 A. F. Eichhorn coll., in the Tring Museum.

\section{Lalage karu falsa Hart.}

Lalage karu falsa Hartert, Nov. Zool. 1925, p. 131 (Duke of York I. New Britain, Rook I., type Duke of York Island).

$5 \hat{\jmath}, 3$ q ad., collected in January. In Nov. Zool. 1925 I have stated the differences between $L . k$. karu from New Ireland, L. $k$. albidior from New Hanover, and L. k. falsa from New Britain, Duke of York, and Rook Island. The series from Talasea fully confirms these differences. Wings $\hat{o} 95-99, q 95,96 \mathrm{~mm}$.

\section{Turdus talasea R. \& H.}

Turdus talasea Rothschild \& Hartert, Bull. B.O.Club, xlvi, p. 53 (January 1926 -Talasea, New Britain).

This fine new Thrush has the upperside greyish slate-colour, darkest on the head, lighter on the rump, and upper tail-coverts, the edges of the feathers with glossless black borders, which get narrower on the rump and disappear on the tail-coverts. Sides of head slaty black with white spots. Underside white, sides lunulated with black edges to the feathers, under tail-coverts white. Quills blackish brown, bases of inner webs from the third white, causing a "Geocichline pattern," the antepenultimate secondary with white edge to the inner web; upper wing-coverts dull black, middle and largest series with big white tips, producing two oblique bars across the wings; outer webs of primaries with greyish-brown edges; under wing-coverts brownish black, the longest with wide white tips, auxiliaries about basal half white, distal half black. Rectrices slaty black, lateral pair with triangular white tip, occupying about half the feather, second pair with triangular white tip about $11 \mathrm{~mm}$. long. "Iris dark brown, bill black, feet light horn-colour." Wing 107, tail $80 \mathrm{~mm}$.

Only a single femiale was obtained by Mr. Eichhorn on February 12, 1925, at an altitude of $1,960 \mathrm{ft}$. It was shot off the nest, which is an oblong cone about $20 \mathrm{~cm}$. long, built of moss, here and there interwoven with rootlets, the neat cup consisting entirely of fine rootlets. The 2 eggs look like small Black- 
birds' eggs with fine rufous spots, more numerous towards the thick end. They are elongated and measure $28 \times 19 \cdot 2$ and $29 \times 19.5 \mathrm{~mm}$.

The discovery of this new species suggests that more unknown birds might yet be found on New Britain. It was shot at 1,900 ft. high, while the mountains south-west of the Gazelle Peninsula are said to be up to 1,600 and even 2,300 m. high, and some near the south coasts seem still to be unexplored.

\section{Dicaeum eximium layardorum Salvad.}

Dicaeum layardorum Salvadori, Ann. Mus. Civ. Genova, xvi, p. 67 (1880-Blanche Bay, New Britain).

A series Talasea January to March. Eichhorn says he found it common, and that it "lives on the local mistletoe (parasite) berries." It seems strange that Dicaeum should live largely on berries, and I do not know which plant is the "mistletoe" of New Britain.

The differences of the two forms, D. e. eximium of New Ireland and New Hanover, and D. e. layardorum of New Britain and Vuatom (teste O. Meyer) have been explained Nov. ZooL., 1924, p. 211. The iris of D. e. layardorum is brownish red or reddish brown, that of $D$. e. eximium dark brown.

\section{Cinnyris sericea corinna (Salvad.).}

Hermotimia corinna Salvadori, Atti R. Accad. Sci., Torino, xiii, p. 532 (1878-Duke of York Island).

Eichhorn found this Sunbird common in Talasea and sent a series shot from January to March.

\section{Cinnyris jugularis flavigastra (Gould).}

Cf. Nov. Zool. 1925, p. 134

A series of beautiful adults of both sexes collected March to beginning of May. Eichhorn says it was found " common on coastal flats." They are very bright, almost orange-yellow underneath.

\section{Myzomela cineracea cineracea Scl.}

Myzomela cineracea Sclater, Proc. Zool. Soc. London, 1879, p. 448, pl. 37 (New Britain) ; cf. Rothschild \& Hartert, Nov. Zool. 1914, p. 217 (Rook Island).

Eichhorn sent 8 (only one female) shot in February, March, and April. " "Iris dark brown. Bill black, feet slaty blue."

As we have said in 1914, not only the young but also the adult females have a rosy-red chin and dark patch on the middle of the throat.

As in other cases this topotypical series is of importance and shows that the birds we mentioned from Rook Island (l.c.) differ somewhat. The colour is the same, but in the series the bill is slightly larger, thicker, the wing, on the other hand, as a rule, a little shorter in the New Britain form, the bill somewhat weaker and the wing longer in the Rook Island form. Wing of Talasea 74-75.5, once $76, q 63$, in one from the Gazelle Peninsula $65 \mathrm{~mm}$.-The wings of the Rook ô $76-78$, $65 \mathrm{~mm}$. I therefore name the latter form

\section{Myzomela cineracea rooki subsp. nov.}

Type: ô ad. Rook Island 24.vii. 1913. No. 5810. A. S. Meek coll.

One is tempted, and it may perhaps be done in future, to make $M$. cineracea a subspecies of $M$. obscura Gould 1842 , but at present it seems to me not advisable, 
because the female of $M$. obscura and its subspecies is like the male, only smaller, not showing red on the chin.

\section{Myzomela erythromelas Salvad.}

Myzomela erythromelas Salvadori, Atti R. Accad. Sc. Torino, xvi, p. 624 (1881-New Britain, discovered by Th. Kleinschmidt); Reichenow, Vög. d. Bismarckinseln, p. 102.

Myzomela guentheri, Gadow, Cat. B. Brit. Mus. p. 129, pl. iii (1884).

Eichhorn sent 6 beautiful adult males, shot by the end of April on the " coastal flats ".; he describes the female, but did not send any. It is a somewhat rare bird, and is only known from New Britain. "Iris dark brown. Bill black. Feet slaty blue." Wings 54-56.5 mm. Some are in moult (tail and back), one showing some olive feathers, proving that the juvenile plumage resembles that of the adult female.

\section{Philemon novaeguineae cockerelli Scl.}

Philemon cockerelli Sclater, Proc. Zool. Soc. London, 1877, p. 104 (New Britain) (not "U.S. Nat, Mus." as given Nov. Zool. xxi. 1914, p. 216 !).

Eight shot in January, one in April. The January specimens have a rather dark upperside, being in perfectly fresh plumage, the April one is a shade paler, while others killed in July and October are much paler, more brown, on the upperside. " Iris dark brown, bill black, feet slaty blue." In one specimen the iris is marked as "grey." Eichhorn found them common. Wings ô 156-160, 우 $155-160 \mathrm{~mm}$.

In Nov. ZooL., 1914, p. 216 , we have already stated that males from Rook Island have wings of 167-168, females of 159-163 mm. Also that they have rather powerful bills. They are therefore a larger race. We said that "we should not be astonished to find this confirmed by comparison with a larger series from New Britain." As this is now the case I name the subspecies from Rook Island :

\section{Philemon novaeguineae umboi, subsp. nov.}

"Umboi " being the native name of Rook Island.

Type: ô Rook Island, 21.vii. 1913. No. 5763. A. S. Meek coll., collected by A. F. Eichhorn, in the Tring Museum.

\section{Pachycephala pectoralis finschi Rehw.}

Cf. Nov. Zool. 1925, p. 132.

Eichhorn found this species common at Talasea and sent a series from January and February. Two of the females show faint cross-bars on the throat, thus reminding one superficially of the females of $P . p$. dahli. The crown is darker (more rufous) brown, or somewhat paler, more olivaceous, in a younger specimen (with horn-brown bill) it is more greenish.

Wings ô $87-91$, ㅇ $85 \mathrm{~mm}$.

\section{Megalurus macrurus interscapularis Sel.}

Cf. Nov. Zool. 1925, p. 134.

Half a dozen specimens were collected at Talasea on May 2 to 9, all in moult.

Eichhorn calls it somewhat rare and saw the nest, " a matted ball of grass in tussock of grass," but he had to leave before eggs were laid, 


\section{Edolisoma morio heinrothi Stres.}

Edolisoma morio heinrothi Stresemann, Orn. Monatsber. 1922, p. 7 (Blanche Bay and Ralum in New Britain).

5 ô, 4 웅 Talasea, January to April. "Iris dark brown" in both sexes. Of the females only one is very old, it has a blue-grey crown, olive-brown back, edges to quills and upper wing-coverts chestnut, underside chestnut-rusty-buff with slaty-black wavy cross-bars to every feather, under tail-coverts uniform rusty. Of the others 3 have black bills and cannot, therefore, be exactly young, but they show a few juvenile wing-coverts and pointed lateral rectrices, which prove that they are only just out of the juvenile dress, and the crowns are still more or less brownish, the underside more or less paler than that of the very adult male. The adult males are very nearly exactly the same as the E. $m$. remotum, but in the series the crown is a shade darker, the bills slightly less powerful.

E. . remotum, rooki, and heinrothi are closely allied, and may be characterised, as follows :

E. $m$. remotum.- ô, bill averaging slightly larger, wing $125-127 \mathrm{~mm}$. q, underside unbarred! Sometimes indications of bars. Habitat: New Ireland, New Hanover, and Feni.

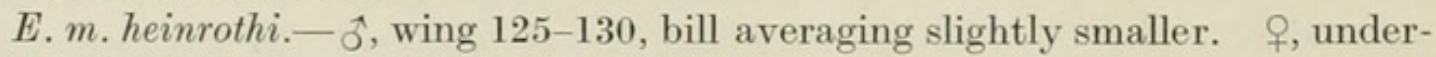
side heavily barred. Habitat: New Britain.

E. m. rooki.-o , wing 121,122 ; 우, as heavily barred as that of heinrothi, but not so rufous (not darker, as Stresemann thought). Habitat: Rook Island.

\section{Graucalus lineatus sublineatus Scl.}

Cf. Nov. Zool. 1925, p. 132.

One female, 27.i.1925. " Iris bright yellow, bill and feet black." Wing $136 \mathrm{~mm}$.

Eichhorn found it rare and says it "lives among the highest tree tops." This may be the reason why the native "boys " who do most of the collecting in these parts may find it difficult to shoot them, which may account for the great rarity in collections.

\section{Graucalus papuensis sclateri Salvad.}

Cf. Nov. Zool. 1925, p. 132.

Not rare at Talasea, series sent from January to March, many moulting wings, tail, body.

\section{Artamus insignis Sel.}

This species, originally described from New Ireland (Nov. ZooL. 1925, p. 136), was common at Talasea. A series was collected in January and February. All specimens showed moult on body, wing, or tail.

\section{Aplonis metallica nitida (Gray).}

Eichhorn observed this starling very common in Talasea. He found it nesting in large trees, the nests often touching each other. The nesting has been well described by Friedrich Dahl and Otto Meyer. A series sent from January to 
March, many moulting. This subspecies extends from St. Matthias Island and from Rook Island over the islands of the Bismarck archipelago to Nissan and Feni, and to the Solomon Islands. (On Vulcan and Dampier Islands A. metallica metallica.) Eats fruit.

\section{Aplonis cantoroides cantoroides (Gray).}

Common at Talasea, fruit-eating, in the coastal districts only. Nests, according to Eichhorn, at the base of the coconut leaves, and in all sorts of holes in trees. Two eggs in the clutch. Half a dozen were shot in April, one on May 8. The May specimen moults some rectrices, the others don't moult. A widespread form, from Mysol to the Bismarck Archipelago and Louisiades ; on Nissan represented by $A$. c. longipennis Neum. Possibly western birds average a little longer in the wing.

\section{Dicrurus bracteatus laemostictus Scl.}

Dicrurus laemostictus Selater, Proc. Zool. Soc. London, 1877, p. 101 (New Britain) ; Nov. Zool. 1914, p. 218 (Rook I.).

Eichhorn sent a series from January which is very valuable to us, being from the original locality, New Britain. Comparing them with the Rook Island specimens it is obvious that the Rook birds are finer-looking, the glossy feathers of the crown of the head and on the chest being a shade more purplish (more greenish in the New Britain ones), the back and abdomen appearing deeper black in the Rook ones. These differences, however, do not seem to be due to locality, as they are not quite constant, and moreover the Rook examples are in finer plumage, having been shot in August, ours from New Britain in January.

\section{Mino dumontii giliau Str.}

Mino dumontii giliau Stresemann, Journ. f. Orn. 1922, p. 406 (Ralum, New Britain).

Stresemann separated this subspecies on account of its smaller white alar speculum and shorter tail from $M . d$. kreffti (terra typica "Solomons Is.") from the Solomons, New Hanover, and New Ireland. The white alar speculum is indeed generally much smaller in giliau, though very variable indeed. I cannot appreciate the supposed shorter tail, as I find specimens with tails 102 and 103 $\mathrm{mm}$., while according to Stresemann they measure only $86-98 \mathrm{~mm}$.

Eichhorn found Mino common at Talasea and collected a series in January and February; all have the body plumage in moult, many also the rectrices. Some have the base of the feathers of the hindneck white, others grey, some have the plumage much more purplish, others more greenish. Such variation is not geographical (it mislead Berlepsch into describing "Mino dumonti violaceus"), and does not seem to be sexual (ef. Nov. ZooL., 1925, p. 135).

\section{Corvus coronoides insularis Heinr.}

Common. Series from January to March. A young bird from March 7. Some February specimens moult body plumage. The sexes differ in size, males having a more powerful bill and longer wings. Wings $\widehat{o} 310-319$, 우 283-290 $\mathrm{mm}$. 


\section{$2 \mathrm{BHL}$ Biodiversity Heritage Library}

Hartert, Ernst. 1926. "On the Birds of the district of Talasea in New Britain." Novitates zoologicae : a journal of zoology in connection with the Tring Museum 33, 122-145. https://doi.org/10.5962/bhl.part.21145.

View This Item Online: https://www.biodiversitylibrary.org/item/22616

DOI: https://doi.org/10.5962/bhl.part.21145

Permalink: https://www.biodiversitylibrary.org/partpdf/21145

\section{Holding Institution}

Natural History Museum Library, London

\section{Sponsored by}

Natural History Museum Library, London

\section{Copyright \& Reuse}

Copyright Status: In copyright. Digitized with the permission of the rights holder.

Rights Holder: The Trustees of the Natural History Museum, London

License: http://creativecommons.org/licenses/by-nc-sa/4.0/

Rights: http://biodiversitylibrary.org/permissions

This document was created from content at the Biodiversity Heritage Library, the world's largest open access digital library for biodiversity literature and archives. Visit BHL at https://www.biodiversitylibrary.org. 